\title{
Mercury Exchange Flux from Two Different Soil Types and Affecting Parameters
}

\author{
Sang-Young Park, Pyung-Rea Kim ${ }^{1)}$ and Young-Ji Han ${ }^{1) *}$ \\ Technical Department, APM Engineering Co., Ltd., 388 Wonmiku, Bucheon, Gyeonggi-do 420-733, Korea \\ ${ }^{1)}$ Department of Environmental Science, College of Natural Science, Kangwon National University, 192-1, Hyoja-2-dong, Chuncheon, \\ Gangwon-do 200-701, Korea \\ *Corresponding author. Tel: +82-33-250-8579, E-mail: youngji@kangwon.ac.kr
}

\begin{abstract}
Mercury exchange fluxes between atmosphere and soil surface were measured in two different types of soils; lawn soil (LS) and forest soil (FS). Average $\mathrm{Hg}$ emission from LS was higher than from FS although the soil $\mathrm{Hg}$ content was more than 2 times higher in forest soil. In LS, $\mathrm{Hg}$ emissions were much greater in warm season than in cold season; however, deposition was dominant in FS during warm season because of leafy trees blocking the solar radiation reaching on the soil surface. In both LS and FS, Hg fluxes showed significantly positive correlations with UV radiation and soil surface temperature during cold season. In addition, it was observed that emission showed positive correlation with UV radiation and soil temperature while there was negative relationship between deposition and UV radiation.
\end{abstract}

Key words: Mercury, Soil, Emission, Deposition, Dynamic flux chamber

\section{INTRODUCTION}

Mercury $(\mathrm{Hg})$ has been considered as a toxic pollutant. It differs from other heavy metals in that it continuously goes through the deposition and re-emission cycle in the environment because of its high vapor pressure (Poissant et al., 2000). Therefore, it is difficult to distinguish between re-emitted $\mathrm{Hg}$ that was previously deposited from atmosphere and $\mathrm{Hg}$ emitted from natural sources. According to the recent report by UNEP (2013), re-emitted $\mathrm{Hg}$ from soil and vegetation accounts for about $19-51 \%$ of the total $\mathrm{Hg}$ currently being emitted and re-emitted to the atmosphere from all sources. When $\mathrm{Hg}$ is deposited on soil surface through wet and dry depositions it remains in the soil as inorganic $\mathrm{Hg}(\mathrm{II})$ compounds (Schuester, 1991), evades to lakes or oceans through runoff (Ahn et al.,
2010), volatilizes to atmosphere (Barkay et al., 2003; Schlüter, 2000; Poissant and Casimir, 1998), or undergoes transformation to methylated $\mathrm{Hg}$, the most toxic form (King et al., 2002). Hence, $\mathrm{Hg}$ exchange between atmosphere and soil is a critical step to track the fate of $\mathrm{Hg}$ in biogeochemical cycle.

Since the soil conditions are typically favorable for the formation of $\mathrm{Hg}(\mathrm{II})$ compounds $\mathrm{Hg}$ should be reduced to $\operatorname{Hg}(0)$, the most volatile form, before volatilization. Previous studies showed that $\mathrm{Hg}$ emissions from soil surfaces are affected by various environmental parameters including solar radiation, temperature and soil wetness especially in controlled environments (Corbett-Hains et al., 2012; Fu et al., 2012; Kocman and Horvat, 2010; Choi and Holsen, 2009a; Yang et al., 2007; Xin et al., 2007); however, there are also many studies which did not observe any clear relationship between $\mathrm{Hg}$ exchange flux and those parameters or did find even opposite trends. Generally, it has been shown that $\mathrm{Hg}$ emission from soil surfaces are positively correlated with solar radiation and temperature, but in a few studies $\mathrm{Hg}$ emissions were significantly enhanced during the nighttime or on cloudy days (Zhang et al., 2008; Engle et al., 2005). Some studies found a positive correlation between $\mathrm{Hg}$ emissions and soil humidity (Gustin and Stamenkovic, 2005; Bahlmann et al., 2004; Scholtz et al., 2003) while others observed the opposite results (Choi and Holsen, 2009a; Gabriel et al., 2006; Wallschlager et al., 2000; Leonard et al., 1998). Other influencing parameters on $\mathrm{Hg}$ exchange flux include $\mathrm{Hg}$ contents and speciation in soil (Corbett-Hains et al., 2012; Fu et al., 2012; Kocman and Horvat, 2010; Choi and Holsen, 2009a; Yang et al., 2007; Xin et al., 2007), atmospheric Hg concentration (Engle et al., 2001), atmospheric oxidants (Engle et al. 2005), and soil properties (organic matter, $\mathrm{pH}$, cation exchange capacity). There are also a number of studies which identified the biological effect on $\mathrm{Hg}$ reduction in soil, but it is not conclusive (Barkay et al., 2003; Schlüter et al., 2000). 
To date there have been only a limited number of studies carried out to determine the combined effects of the parameters that influence $\mathrm{Hg}$ emissions from soil. In Korea, there was only one study to estimate $\mathrm{Hg}$ emission flux from soil surfaces using micrometeorological gradient method in Seoul (Kim and Kim, 1999). This study is the first study that directly measured the $\mathrm{Hg}$ exchange flux between soil and atmosphere using dynamic flux chamber (DFC) in Korea. In this study, $\mathrm{Hg}$ fluxes were measured from two different types of lands including forest and lawn in cold and warm seasons, and compared with various environmental parameters.

\section{MATERIALS AND METHODS}

\section{1 Measurements}

Air-soil $\mathrm{Hg}$ fluxes were measured from the forest soils (FS) and lawn soil (LS) in the campus of Kangwon National University in South Korea using dynamic flux chamber (DFC). The lawn site was completely covered by about $3 \mathrm{~cm}$ tall grasses, and the mixed forest site (deciduous and coniferous forest canopy) was covered by a $1 \sim 2 \mathrm{~cm}$ of fallen leaves. The sampling periods were Feb. 22 25 and May 28 30, 2011 for the lawn site, and Feb. 25 27 and June 13 15, 2011 for the forest site, including cold and warm seasons.

A cylindrical polycarbonate DFC (3.78 L) was used in this study similar to that used by Choi and Holsen (2009a, 2009b). The diameter of the DFC opening over the soil surface was $18 \mathrm{~cm}$, and four inlet holes ( $1 \mathrm{~cm}$ diameter) were evenly distributed around the chamber wall to insure the chamber was well mixed. A detailed description and diagram can be found in Choi and Holsen (2009a). The edges of chambers were placed $3 \mathrm{~cm}$ under the soil surface, and deployed one week before measurements started for each sampling period. $\mathrm{Hg}$ concentrations in inlet $\left(\mathrm{C}_{\mathrm{in}}\right)$ and outlet $\left(\mathrm{C}_{\text {out }}\right)$ were alternatively measured using Tekran 1110 synchronized two-port sampling unit and Tekran 2537B analyzer (cold vapor atomic fluorescence spectrophotometry), and $10 \mathrm{~min}$ average of $\mathrm{C}_{\text {in }}$ and $\mathrm{C}_{\text {out }}$ were measured to calculate the $\mathrm{Hg}$ emission flux every $20 \mathrm{~min}$ using equation (1).

$$
F=\left(C_{\text {out }}-C_{\text {in }}\right) \times Q / A
$$

where $F$ is $\mathrm{Hg}$ emission flux in $\mathrm{ng} \mathrm{m}^{-2} \mathrm{~h}^{-1}, C_{\text {out }}$ and $C_{i n}$ are concentrations of $\mathrm{Hg}$ at the outlet and inlet in $\mathrm{ng} \mathrm{m}^{-3}$, respectively, $Q$ is the flushing flow rate through the chamber in $\mathrm{m}^{3} \mathrm{~h}^{-1}$, and $A$ is the surface area of the soil exposed in the chamber in $\mathrm{m}^{2}$. The optimum flushing rate, $Q$ of $5 \mathrm{Lpm}$ was chosen since the best consistent recovery of standard $\mathrm{Hg}$ vapor was yielded as in
Choi and Holsen (2009a, 2009b). A positive value of $F$ indicates the net $\mathrm{Hg}$ emission from the soil surface while a negative value indicates the net $\mathrm{Hg}$ deposition to the soil surface. It should be noted that the transmission of UVA, UVB and UVC through a polycarbonate chamber are 88,28 , and $0 \%$, respectively (Skinner, 1998); therefore, there is a possibility that $\mathrm{Hg}$ emission flux was underestimated in field measurements (Carpi et al., 2007).

LS and FS were collected $5 \sim 7 \mathrm{~cm}$ below the surface to measure soil properties and $\mathrm{Hg}$ contents in soils. After collected soil was freeze-dried and homogenized, the total $\mathrm{Hg}$ content in soil was measured using a DMA 80 automatic $\mathrm{Hg}$ analyzer (Milestone, Inc.). Soil organic matter and organic carbon were determined by loss on ignition (LOI) (Nelson and Sommers, 1996). Soil $\mathrm{pH}$ was measured by soaking in distilled water. Soil particle size distribution was measured using the hydrometer method (Bohn and Gebhardt, 1989; Bouyoucos, 1962).

\section{2 Environmental Parameters}

Environmental parameters including soil surface temperature and soil relative humidity were measured every 5 min on site using a HOBO data logger (U23001, onset, INC., USA) which was placed $3 \mathrm{~cm}$ under the soil surface. UVA was measured with a UV-A light meter (YK-37UV3D, Lutron, Inc., Taiwan). Meteorological data including solar radiation, air temperature, and atmospheric relative humidity were obtained from Chuncheon meteorological observatory in Korea where is located approximately $3.46 \mathrm{~km}$ north of the sampling site. Ozone $\left(\mathrm{O}_{3}\right)$ concentration was obtained from national monitoring site located approximately $1.5 \mathrm{~km}$ south of the sampling site.

\section{3 QA/QC}

The Tekran 2537B was calibrated with its internal permeation source before the sampling. It was also manually calibrated using injection of $\mathrm{Hg}^{0}$ saturated vapor. $\mathrm{R}^{2}$ was $>0.9995$ using five point manual injection, and the recoveries were $108.1 \pm 1.6 \%$ and 102.5 $\pm 2.7 \%$ for cartridge A and B, respectively. RSD (relative standard deviation) was $3.3 \pm 1.3 \%$ from 7 injections of $\mathrm{Hg}^{0}$ saturated vapor. The concentration difference between inlet and outlet was less than $5 \%$ when DFC was placed on the baked aluminum foil with no light.

For analysis of $\mathrm{Hg}$ content in soils, a standard curve was obtained ( $0.5 \mathrm{ppb}$ to $2 \mathrm{ppm})$ and $\mathrm{R}^{2}$ was $>0.999$. SRM (standard reference materials: MESS 3, marine sediment, NIS) was used to calculate the accuracy and precision, and recovery ranged from 102 to $108 \%$. The method detection limit (MDL) was $0.029 \mu \mathrm{g} \mathrm{kg}^{-1}$, cal- 
Table 1. Selected soil properties and total $\mathrm{Hg}$ content in soil surface at the sampling site.

\begin{tabular}{|c|c|c|c|c|c|c|c|c|}
\hline \multirow{2}{*}{ Date } & \multirow{2}{*}{ Site } & \multirow{2}{*}{$\underset{\left(\mu \mathrm{g} \mathrm{kg}^{-1}\right)}{\mathrm{THg}}$} & \multicolumn{3}{|c|}{ Particle size distribution (\%) } & \multirow{2}{*}{$\mathrm{OM}(\mathrm{wt} \%)$} & \multirow{2}{*}{$\mathrm{OC}(\mathrm{wt} \%)$} & \multirow{2}{*}{$\mathrm{pH}$} \\
\hline & & & Sand & Silt & Clay & & & \\
\hline $2011.02 .22 \sim 25$ & Lawn & 32.3 & 74.4 & 14.5 & 11.2 & 4.6 & 2.7 & 6.7 \\
\hline $2011.05 .28 \sim 30$ & Lawn & 37.2 & 78.4 & 13.0 & 8.6 & 4.8 & 2.8 & 6.5 \\
\hline $2011.02 .25 \sim 28$ & Forest & 76.1 & 85.5 & 7.2 & 7.2 & 11.6 & 6.7 & 4.4 \\
\hline $2011.06 .13 \sim 15$ & Forest & 78.5 & 85.5 & 8.3 & 6.2 & 10.8 & 6.3 & 4.8 \\
\hline
\end{tabular}

culated as three times the standard deviation of seven sequential analyses of SRMs.

\section{RESULTS AND DISCUSSION}

\section{1 Basic Properties of Soils}

The $\mathrm{Hg}$ content in the FS (77.3 $\mu \mathrm{g} \mathrm{kg}^{-1}$ in average) was more than 2 times higher than that in the LS (34.8 $\left.\mu \mathrm{g} \mathrm{kg}^{-1}\right)$, and there was no difference between the soils collected during different times of the year (Table 1). Organic matter (OM) and organic carbon (OC) content were also higher for FS than for LS. Soil OM has been suggested as effective binding site for $\mathrm{Hg}$ (II), resulting in a positive correlation between $\mathrm{Hg}$ content and $\mathrm{OM}$ content in soil (Yang et al., 2007; Meili, 1991). The contribution of sand was higher for FS than for LS, indicating that the porosity of FS was probably greater than for the LS. The average $\mathrm{pH}$ was 6.6 and 4.6 for the LS and FS, respectively.

\section{3. $2 \mathrm{Hg}$ exchange in Lawn Soil}

$\mathrm{Hg}$ emission-deposition fluxes varied significantly with sampling location and time. Twenty-min fluxes were smoothed using the Savitzky-golay method in this study (Savitzky and Golay, 1964). For the lawn soil (LS) the $\mathrm{Hg}$ emission was statistically larger in May, $2011\left(7.8 \pm 12.8 \mathrm{ng} \mathrm{m}^{-2} \mathrm{hr}^{-1}\right)$ than in February 2011 $\left(0.2 \pm 5.4 \mathrm{ng} \mathrm{m}^{-2} \mathrm{hr}^{-1}\right)$ (Fig. 1). In February the soil temperature dropped to nearly $0^{\circ} \mathrm{C}$ at night in the lawn, resulting in low emission fluxes and the occurrence of frequent deposition as suggested in previous studies (Corbett-Hains et al., 2012; Choi and Holsen, 2009a). On the other hand, most of $\mathrm{Hg}$ flux occurred as emission in May when soil temperate ranged 15 to $33^{\circ} \mathrm{C}$ and UV-A radiation increased to $2.8 \mathrm{~mW} \mathrm{~cm}^{-2}$. In February, $\mathrm{Hg}$ emission flux generally increased with increases in UVA radiation and soil temperature during daytime; however, there was no distinct diurnal variation observed in May (Table 2, Fig. 1). Previous researches suggested that $\mathrm{Hg}$ emission flux from soils was positively correlated with soil surface temperature and solar radiation especially in laboratory investigation (Kocman and Horvat, 2010; Lin et al., 2010; Choi and Holsen, 2009a); however, it was also often observed that there was no significant relationship between $\mathrm{Hg}$ emission flux and environmental parameters in field experiments (Stamerkovic et al., 2008; Ericksen et al., 2006). For example, a peak of $\mathrm{Hg}$ emission flux (58.1 $\mathrm{ng} \mathrm{\textrm {m } ^ { - 2 }} \mathrm{hr}^{-1}$ ) occurred from LS during early morning (around $2 \mathrm{am}$ ) on May $29^{\text {th }}$ when soil temperature and UV-A radiation were low; however, early morning peak was not shown on May 30th (Fig. 1). Several studies also found a significant increase of $\mathrm{Hg}$ emission at nighttime (Zhang et al., 2008; Engle et al., 2005; Zhang and Lindberg, 1999) and suggested the role of atmospheric oxidants as a possible reason. In this study, there was no positive relationship between $\mathrm{O}_{3}$ concentration and $\mathrm{Hg}$ emission flux throughout the whole sampling period; however, generally higher ozone concentrations were observed during 1-11 am on May $29^{\text {th }}(37.1 \mathrm{ppb})$ when $\mathrm{Hg}$ emission flux increased (Fig. 1) than those during the same time on May 30th (19.2 ppb). According to Engle et al. (2005), $\mathrm{O}_{3}$ showed similar influence on increasing $\mathrm{Hg}^{0}$ emissions from substrates to light especially when the substrate was relatively dry. Soil RH during early morning on May 30 was significantly lower than on May 29, suggesting that both low soil $\mathrm{RH}$ and high atmospheric $\mathrm{O}_{3}$ concentration could derive the increased $\mathrm{Hg}$ emission flux from soil surface. The chemical mechanisms that produced the trends between $\mathrm{O}_{3}$ and $\mathrm{Hg}$ emission are not known but potentially involve heterogeneous reactions between $\mathrm{O}_{3}$, the substrate, and $\mathrm{Hg}$ (Engle et al., 2005).

In addition, Poissont and Casimir (1998) found that there was a positive correlation between water vapor flux and $\mathrm{Hg}$ emission flux, suggesting that water vapor is a good tracer gas to derive the turbulent mixing coefficient for $\mathrm{Hg}$. The atmospheric RH even exceeded the $\mathrm{RH}$ in soil during early morning on May 30, possibly limiting the volatilization of water vapor and associated $\mathrm{Hg}$ from the soil surface in this study. On the other hand, Erickson et al. (2006) indicated that increase of $\mathrm{Hg}$ emission was the result of the soil $\mathrm{Hg}$ pool replenishing in the absence of light. These results indicate that the emission-deposition process is affected by many multiple and interacting factors; therefore, it did not often show strong correlation with just one individual parameter in this present study. 

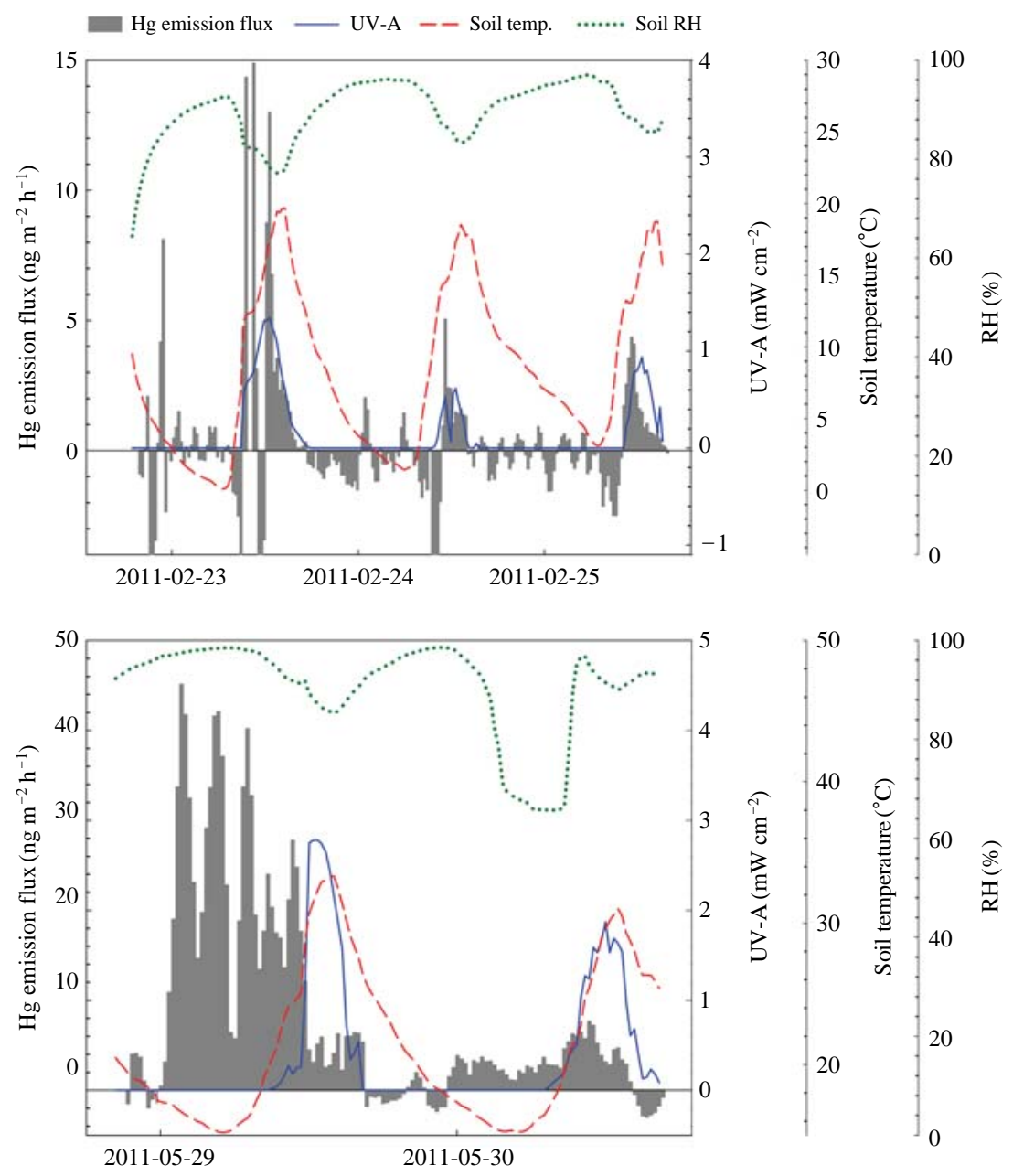

Fig. 1. Hg exchange flux between soil and air at the lawn soil (LS). The positive and negative values indicate emission and deposition, respectively.

Table 2. Comparison of $\mathrm{Hg}$ emission fluxes from soil surfaces with other studies.

\begin{tabular}{|c|c|c|c|c|c|}
\hline Site & Soil type & Period & $\begin{array}{l}\mathrm{Hg} \text { conc. in soil } \\
\left(\mu \mathrm{g} \mathrm{g}^{-1}\right)\end{array}$ & $\begin{array}{l}\text { Hg emission flux } \\
\left(\mathrm{ng} \mathrm{m}^{-2} \mathrm{hr}^{-1}\right)\end{array}$ & Reference \\
\hline \multirow[t]{2}{*}{ Guangdong, China } & Bare soil & Dec. & $0.03 \sim 1.88$ & $2.7 \sim 135$ & \multirow[t]{2}{*}{ Fu et al., 2012} \\
\hline & Forest soil & Dec. & 0.13 & 6.6 & \\
\hline \multirow[t]{2}{*}{ Mt. Gongga, China } & Forest soil & Aug. Sep. & $0.06 \sim 0.18$ & $0.5 \sim 9.3$ & \multirow[t]{2}{*}{ Fu et al., 2008} \\
\hline & Grassland & Aug. & $0.14 \sim 0.17$ & $-1.7 \sim 20.4$ & \\
\hline Guiyang, China & Bare soil & May, June & $0.15 \sim 0.63$ & $0.4 \sim 44.4$ & Fang et al., 2004 \\
\hline Seoul, Korea & Bare soil & Sep. & 0.24 & 96.0 & Kim and Kim, 1999* \\
\hline Adirondack, USA & Forest soil & Spring & - & 1.6 & Choi and Holsen, 2009a \\
\hline Background sites, & Grassland & Jul. Aug. & - & 1.3 & Ericksen et al., 2006 \\
\hline USA & Mixed forest & - & - & 1.1 & \\
\hline \multirow[t]{2}{*}{ Canada } & Bare soil & - & $0.01 \sim 0.03$ & $3.0 \sim 5.9$ & Schroeder et al., 2005 \\
\hline & Forest soil & - & $0.15 \sim 0.33$ & $-0.4 \sim 2.2$ & Poissant and Casimir, 1998 \\
\hline \multirow[t]{4}{*}{ Chuncheon, Korea } & LS & Feb. & 0.03 & $-13.7 \sim 14.9(0.2 \pm 5.4)$ & \multirow[t]{4}{*}{ This study } \\
\hline & & May & 0.04 & $-6.3 \sim 45.1(7.8 \pm 12.8)$ & \\
\hline & FS & Feb. & 0.08 & $-2.3 \sim 2.1(0.2 \pm 2.1)$ & \\
\hline & & June & 0.08 & $-13.6 \sim 3.5(-6.2 \pm 3.5)$ & \\
\hline
\end{tabular}

*Fluxes were estimated based on $\mathrm{Hg}$ concentration gradients at two heights. For all others, fluxes were directly measured using DFC 

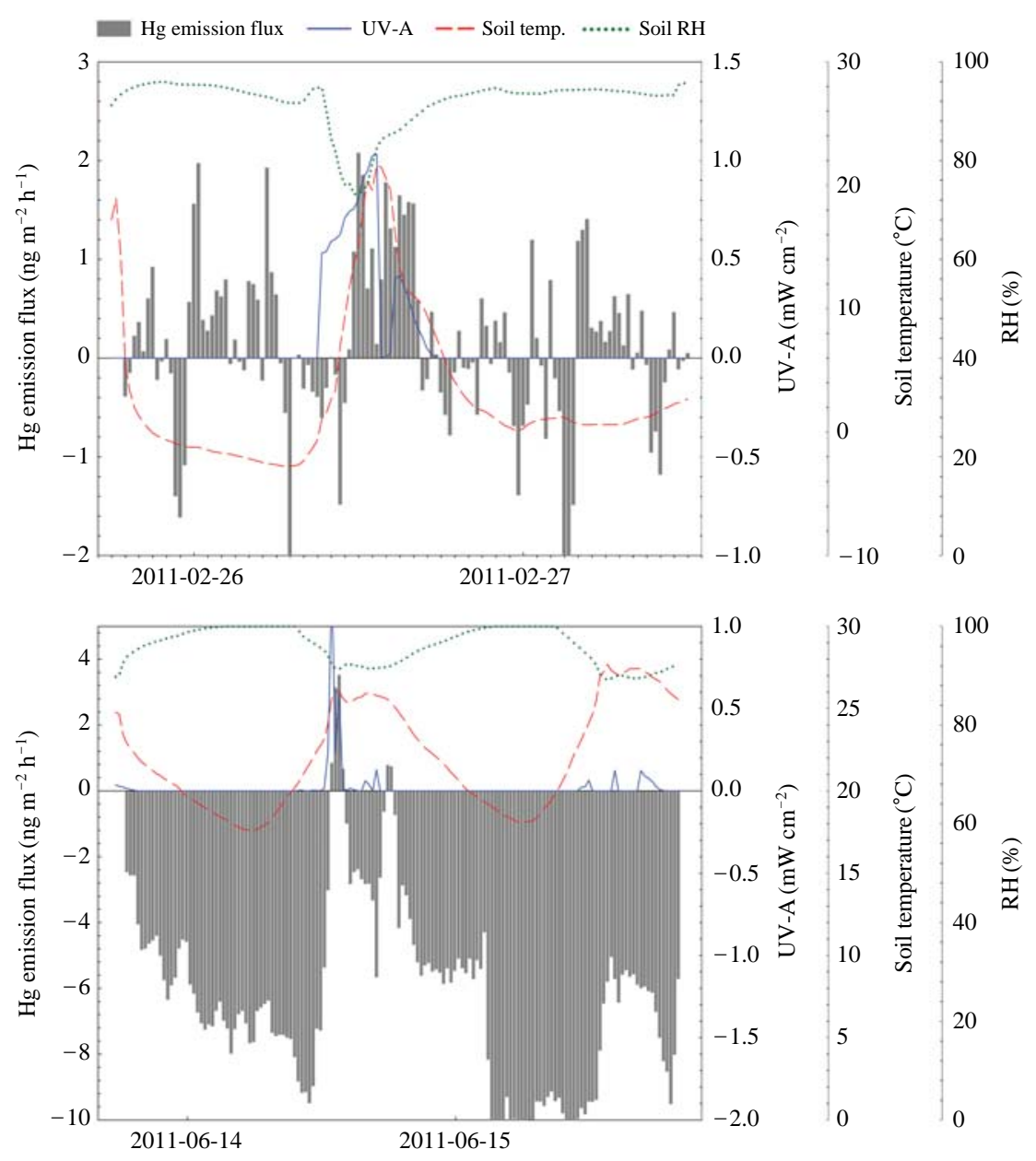

Fig. 2. Hg exchange flux between soil and air at the forest soil(FS). The positive and negative values indicate emission and deposition, respectively.

\section{3. $3 \mathrm{Hg}$ Exchange in Forest Soil}

In forest soil (FS) the $\mathrm{Hg}$ emission fluxes were higher in winter (Feb. 25-28, 2011) than in summer (June 1315, 2011) (Fig. 2), which was opposite of those observed in LS (Fig. 1). Also, although the $\mathrm{Hg}$ content in FS was more than 2 times higher than in LS, Hg emission flux was not observed to be higher in FS. Organic matter has been suggested to either facilitate or inhibit $\mathrm{Hg}$ reduction in previous researches, but it typically shows the extremely high affinity with $\mathrm{Hg}$, resulting in low availability/mobility in soil (Mauclair et al., 2008; Skyllberg et al., 2006) while $\mathrm{Hg}$ reduction often increases with an increase of organic matter in natural water (Ahn et al., 2010; Zhang and Lindberg, 2001; Allard and Arsenie, 1991). In this study, higher organic matter content in FS possibly reduced the $\mathrm{Hg}$ emission despite of higher $\mathrm{Hg}$ content in soil than in LS. In addition, UV radiation was relatively low for the FS due to the cloudy condition during sampling, and fal- len leaves and vegetation left inside chamber probably limited the solar radiation reached on the soil surface. During winter, high $\mathrm{Hg}$ emission flux was observed when soil temperature and UV-A radiation increased; however, throughout the sampling, the variation of $\mathrm{Hg}$ emission flux did not clearly follow the variation of temperature and/or UV radiation for the forest site (Fig. 2). When $\mathrm{Hg}$ emission flux was measured in Adirondack forest, USA (Choi, 2007) its correlation with temperature or solar radiation was not observed in coniferous forest while there was a significant correlation in deciduous forest, and it was suggested that the bacteria in the coniferous soils primarily engage in the oxidation of $\mathrm{Hg}$ rather than reduction of $\mathrm{Hg}$ (Smith et al., 1998). The forest in this study was mixed with coniferous and deciduous trees, possibly resulting in unclear correlation of $\mathrm{Hg}$ emission flux with temperature or UV radiation. In addition, there is a possibility that bacteria can alter soil properties including soil 
moisture and $\mathrm{pH}$, indirectly affecting the $\mathrm{Hg}$ emissiondeposition cycle.

In June $\mathrm{Hg}$ flux mostly appeared as deposition direction despite of high soil temperature (Fig. 2). UV radiation reached on soil surface was zero for most of times because the forest canopy was shading the forest floor, but the direction of flux changed to emission from deposition when UV radiation increased to 1.3 $\mathrm{mW} \mathrm{cm}{ }^{-2}$ during a very short time in the afternoon on June $14^{\text {th }}$ (Fig. 1). Soil surface temperature also increased during that short time; however, it increased again in afternoon of June $15^{\text {th }}$ when $\mathrm{Hg}$ emission flux and UV radiation were not observed (Fig. 2). This result indicates that radiation is indeed an important factor for $\mathrm{Hg}$ emission from the soil surface. Increased $\mathrm{Hg}$ deposition to soil surfaces during summer was also reported in previous researches (Choi and Holsen, 2009a; Choi, 2007).

In previous studies, $\mathrm{Hg}$ exchange fluxes between atmosphere and soil were measured in different soil types. In Korea, there was only one study to estimate the $\mathrm{Hg}$ exchange flux, and the average emission flux was $96.0 \mathrm{ng} \mathrm{m}^{-2} \mathrm{hr}^{-1}$ (Kim and Kim, 1999), a much higher flux than those found in this study (Table 2). In the study of Kim and Kim(1999), Hg exchange fluxes were measured using gradient measurement method while DFC was used in this study. Also, the sampling site of Kim and Kim (1999) was located in the residential area of the metropolitan (Seoul), which probably caused greater $\mathrm{Hg}$ accumulation in soil due to the nearby anthropogenic $\mathrm{Hg}$ sources when compared with the sites in this study. $\mathrm{Hg}$ emission fluxes in forest soil were consistently less than those in bare soil in Guangdong and Mt. Gongga in China while the Hg concentration in soils were comparable between bare and forest soils (Table 2), indicating that $\mathrm{Hg}$ emission flux cannot be estimated only by soil $\mathrm{Hg}$ content. Higher $\mathrm{Hg}$ emission fluxes in LS than in FS were also observed in this study although the soil $\mathrm{Hg}$ contents showed the opposite order. The $\mathrm{Hg}$ emission fluxes in LS in this study were generally higher than those observed in USA and Canada, but clearly lower than in urban sites in China (Guangdong and Guiyang, China).

\section{4 Relationship with Environmental Parameters}

Relative frequency distribution of hourly soil $\mathrm{Hg}$ flux in FS and LS for each season was shown in Fig. 3. In $\mathrm{FS}$, the bulk of the soil $\mathrm{Hg}$ flux measurements were between -0.5 and $0.5 \mathrm{ng} \mathrm{m}^{-2} \mathrm{hr}^{-1}$ in February; however, most of $\mathrm{Hg}$ exchange was shown as depositional flux in June because the forest canopy was shading the forest floor, resulting in almost no solar radiation reached the soil surface. The lowest minimum hourly

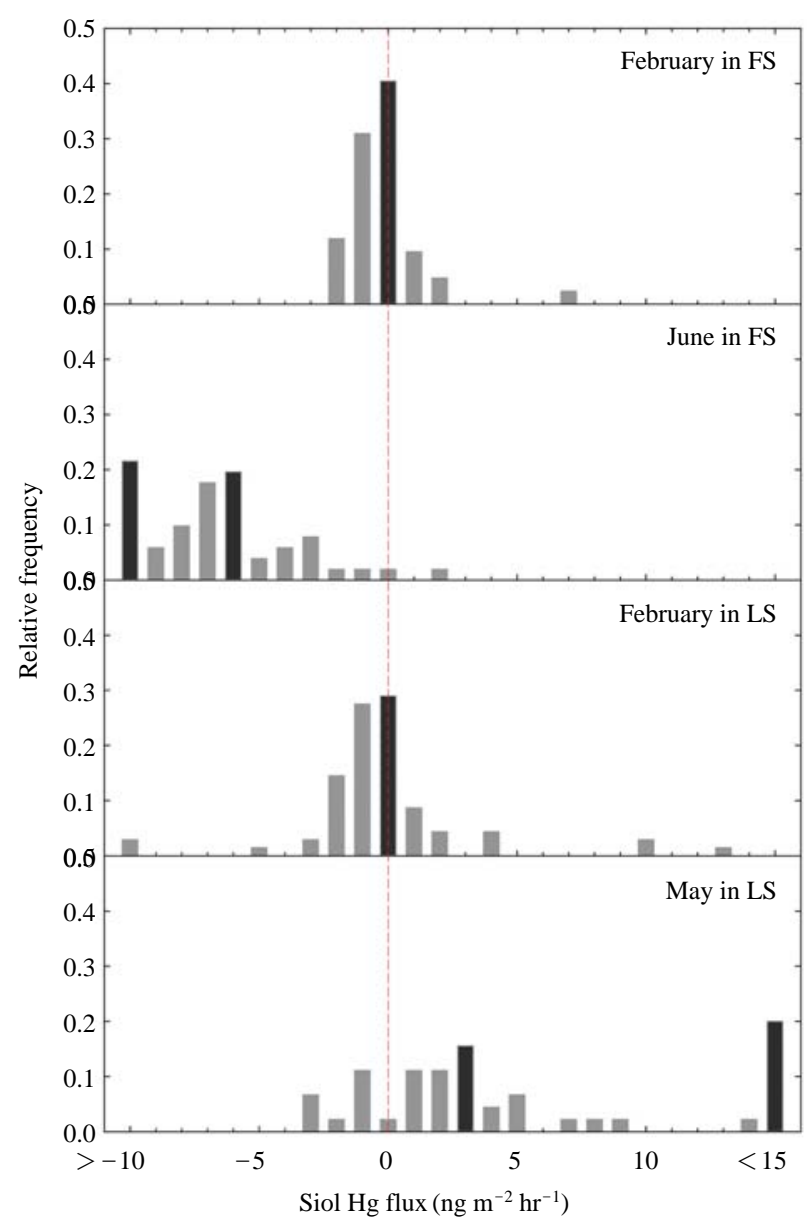

Fig. 3. Histograms of relative frequency of soil $\mathrm{Hg}$ flux at FS and LS in each season.

$\mathrm{Hg}$ flux was -2 and $-12 \mathrm{ng} \mathrm{m}^{-2} \mathrm{hr}^{-1}$ in FS in February and June, respectively. Frequency distribution in LS was very similar to FS in February, showing -0.5 $-0.5 \mathrm{ng} \mathrm{m}^{-2} \mathrm{hr}^{-1}$ as a dominant flux (Fig. 3). On the other hand, significant shift to the emission flux was observed in warm season (May) in LS, showing the opposite seasonal trend to FS. In May, the emission flux higher than $15 \mathrm{ng} \mathrm{m}^{-2} \mathrm{hr}^{-1}$ was dominant in frequency distribution in LS, having the highest maximum hourly $\mathrm{Hg}$ flux of $33 \mathrm{ng} \mathrm{m}^{-2} \mathrm{hr}^{-1}$.

In order to identify the relationship of $\mathrm{Hg}$ flux with environmental variables the Pearson correlation coefficients were calculated. During winter (Feb. 2011), Hg flux showed significantly positive correlation with UV radiation and soil surface temperature in both sites (Table 3), suggesting that UV radiation and/or soil temperature were important for $\mathrm{Hg}$ emission when the soil surface temperatures were low (the soil surface temperatures were $8.3^{\circ} \mathrm{C}$ and $3.2^{\circ} \mathrm{C}$ in $\mathrm{LS}$ and $\mathrm{FS}$ on average, respectively, and often dropped below $0^{\circ} \mathrm{C}$ ). 
Table 3. Correlation coefficient (p-value) between $\mathrm{Hg}$ emission flux with environmental parameters.

\begin{tabular}{|c|c|c|c|c|}
\hline & \multicolumn{2}{|c|}{ Lawn soil (LS) } & \multicolumn{2}{|c|}{ Forest soil (FS) } \\
\hline & $2011.02 .22 \sim 25$ & $2011.05 .28 \sim 30$ & $2011.02 .25 \sim 28$ & $2011.06 .13 \sim 15$ \\
\hline UV-A radiation & $0.385(<0.001)$ & $-0.155(0.076)$ & $0.262(0.003)$ & $0.479(<0.001)$ \\
\hline Soil surface temp. & $0.271(<0.001)$ & $-0.311(<0.001)$ & $0.412(<0.001)$ & $-0.506(<0.001)$ \\
\hline Soil RH & $-0.252(<0.001)$ & $0.287(0.001)$ & $-0.305(0.001)$ & $0.352(<0.001)$ \\
\hline
\end{tabular}
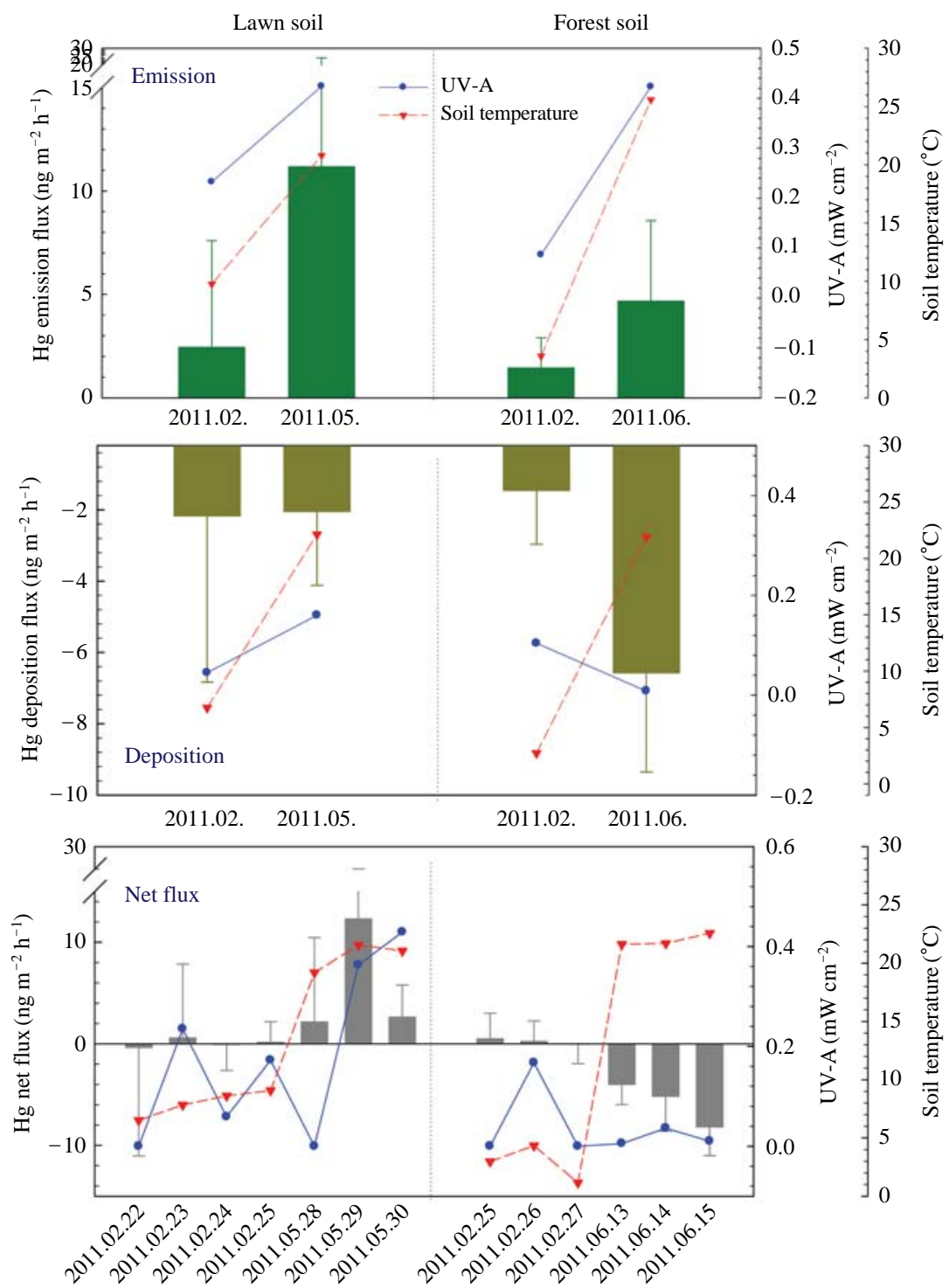

Fig. 4. Daily averaged $\mathrm{Hg}$ emission (top panel), deposition (middle panel), and net flux (bottom panel) in the LS (left) and FS (Right).

In addition, in both sites, there was a negative relationship between $\mathrm{Hg}$ emission flux and soil RH during winter. Soil RH generally decreased when soil temperature increased (Figs. 1, 2); therefore, it is not conclusive that soil RH was the important individual factor affecting on $\mathrm{Hg}$ emission. In May $\mathrm{Hg}$ emission flux was observed to be the highest in the LS; however, it showed a statistical negative correlation with soil temperature and a positive correlation with soil RH(Table 3). As discussed earlier, a peak of $\mathrm{Hg}$ emission appear- 
ed during early morning (around $2 \mathrm{am}$ ) on May $29^{\text {th }}$ was possibly explained by high $\mathrm{O}_{3}$ concentration and low soil RH. In FS, there was a significantly positive relationship of $\mathrm{Hg}$ emission flux with soil temperature and/or UV radiation in February and June (Table 3). A less significant result for correlations between $\mathrm{Hg}$ emission flux and environmental parameters was derived either by short sampling duration or by effect of multiple interacting factors. One possible factor is the oxidation effect of bacteria for FS (Choi, 2007; Smith et al., 1998; Hamlett et al., 1992; Summers and Silver, 1972).

Since emission-deposition cycle greatly affects on the transport and fate of $\mathrm{Hg}$ in multimedia environments the averaged $\mathrm{Hg}$ emission and deposition fluxes for each sampling event were separately compared with environmental parameters for each sampling event in LS and FS (Fig. 4). Average volatilization flux generally increased with increases on UV radiation and soil surface temperature for LS and FS, showing higher flux in warm season while the deposition flux showed negative relationship with UV-A radiation (Fig. 4). In FS, the highest emission and deposition fluxes concurrently occurred during warm season (June, 2011), indicating that deposition may be as important as emission for the forest floors in warm season because of the limited solar radiation reaching on soil surface due to the leafy trees. On the other hand, deposition flux for LS was relatively consistent over the sampling periods. In overall, the deposition flux was not affected by soil surface temperature.

Daily averaged net flux showed higher emission flux with an increase of soil surface temperature (Spearman rank order correlation coefficient, $r_{s}=0.673$, $p$-value $=0.033)$ and soil humidity $\left(\mathrm{r}_{\mathrm{s}}=0.709, \mathrm{p}\right.$-value $\left.=0.022\right)$ for LS while it did not have significant correlation with any environmental parameters for FS. This result possibly suggests that fallen leaves on forest floor acted as an inhibitor for showing strong relationship between $\mathrm{Hg}$ emission flux and environmental parameters by limiting the amount of heat and solar radiation reaching the forest floor.

\section{CONCLUSIONS}

In this study, $\mathrm{Hg}$ exchange fluxes between atmosphere and soil surface were observed in two types of soils (LS and FS) in cold (February) and warm (May, June) seasons. Hg emission was much higher during warm season in LS; however, in FS, Hg deposition was frequently observed in warm season probably because of leafy trees blocking the solar radiation. When UV radiation suddenly increased during a very short time in FS in June, the direction of flux abruptly changed from deposition to emission, showing the influence of radiation on $\mathrm{Hg}$ emissions.

In cold seasons, $\mathrm{Hg}$ fluxes showed significantly positive correlations with UV radiation and soil surface temperature in both soils; however, concurrent variations between $\mathrm{Hg}$ flux and environmental parameters were not clearly observed in warm season. In LS, $\mathrm{Hg}$ emission flux was possibly affected by enhanced atmospheric oxidants as well as other environmental parameters in warm season, resulting in ambiguous diurnal variation. When the $\mathrm{Hg}$ emission and deposition fluxes for each sampling event were separately compared with environmental parameters average volatilization flux generally increased with increases on UV-A radiation and soil surface temperature for both sites while the deposition flux showed negative relationship with UV-A radiation. There were also statistically significant relationships between daily averaged net $\mathrm{Hg}$ flux with soil surface temperature and soil humidity in LS.

Average $\mathrm{Hg}$ emission from LS was higher than from FS although the $\mathrm{Hg}$ content in soil was more than 2 times higher in FS, indicating that total amount of $\mathrm{Hg}$ in soil was not a primary indicator for $\mathrm{Hg}$ emission flux in this study. Hg emission fluxes from LS in this study were generally lower than in urban sites in Korea and China, but higher than those measured in USA and Canada. It should be noted that a polycarbonate chamber possibly underestimated the $\mathrm{Hg}$ emission flux because it blocks most of the UV-B light (Carpi et al., 2007) although in the study of Choi and Holsen (2009a) it did not impact the results significantly. In addition, the relatively higher flushing rate compared with small DFC volume could enhance the emission flux (Eckley et al., 2010; Lindberg et al., 2002), bringing the possibility of overestimation on flux measurement in this study.

\section{ACKNOWLEDGEMENT}

This research was supported by Basic Science Research Program through the National Research Foundation of Korea (NRF) funded by the Ministry of Education, Science and Technology (2012R1A1A2042150).

\section{REFERENCES}

Ahn, M.C., Kim, B., Holsen, T.M., Yi, S.M., Han, Y.J. (2010) Factors influencing concentrations of dissolved gaseous mercury (DGM) and total mercury (TM) in an artificial reservoir. Environmental Pollution 158, 347- 
355.

Allard, B., Arsenie, I. (1991) Abiotic reduction of mercury by humic substances in aquatic system - an important process for the mercury cycle. Water Air Soil Pollution $56,457-464$.

Bahlmann, E., Ebinghaus, R., Ruch, W. (2004) The effect of soil moisture on the emission of mercury from soils. RMZ - Mater Geoenviron 51, 791-794.

Barkay, T., Miller, S.M., Summers, A.O. (2003) Bacterial mercury resistance from atoms to ecosystems. FEMS Microbiology Reviews 27, 355-384.

Bohn, C.C., Gebhardt, K. (1989) Comparison of hydrometer settling times in soil particle size analysis. Journal of Range Management 42(1), 81-83.

Bouyoucos, G.J. (1962) Hydrometer method improved for making particle size analysis of soils. Agronomy Journal 54, 464-465.

Carpi, A., Frei, A., Cocris, D., McCloskey, R., Contreras, E., Ferguson, K. (2007) Analytical artifacts produced by a polycarbonate chamber compared to a Teflon chamber for measuring surface mercury fluxes. Analytical and Bioanalytical Chemistry 388, 361-365.

Choi, H.D. (2007) Mercury inputs, outputs, cycling and ambient concentrations under the forest canopy in the Adirondacks of New York, Ph.D. thesis, Clarkson University.

Choi, H.D., Holsen, T.M. (2009a) Gaseous mercury fluxes from the forest floor of the Adirondacks. Environmental Pollution 157, 592-600.

Choi, H.D., Holsen, T.M. (2009b) Gaseous mercury emissions from unsterilized and sterilized soils: The effect of temperature and UV radiation. Environmental Pollution 157, 1673-1678.

Corbett-Hains, H., Walters, N.E., Heyst, B.J.V. (2012) Evaluating the effects of sub-zero temperature cycling on mercury flux from soils. Atmospheric Environmental 63, 102-108.

Eckley, C.S., Gustin, M., Lin, C.-J., Li, X., Miller, M.B. (2010) The influence of dynamic chamber design and operating parameters on calculated surface-to-air mercury fluxes. Atmospheric Environmental 44, 194-203.

Engle, M.A., Gustin, M.S., Zhang, H. (2001) Quantifying natural source mercury emissions from the Ivanhoe Mining District, north-central Nevada, USA. Atmospheric Environmental 35, 3987-3997.

Engle, M.A., Gustin, M.S., Lindberg, S.E., Gertler, A.W., Ariya, P.A. (2005) The influence of ozone on atmospheric emissions of gaseous elemental mercury and reactive gaseous mercury from substrates. Atmospheric Environmental 39, 7506-7517.

Ericksen, J.A., Gustin, M.S., Xin, M., Weisberg, P.J., Fernandez, G.C.J. (2006) Air-soil exchange of mercury from background soils in the United States. Science of the Total Environment 366, 851-863.

Fang, F.M., Wang, Q.C., Li, J.F. (2004) Urban environmental mercury in Changchun, a metropolitan city in northeastern China: source, cycle, and fate. Science of the Total Environment 330, 159-170.
Fu, X.W., Feng, X.B., Wang, S.F. (2008) Exchange fluxes of $\mathrm{Hg}$ between surfaces and atmosphere in the eastern flank of Mount Gongga, Sichuan province, south-western China. Journal of Applied Geophysical Research 113 (D20306). Doi:10.1029/2008JD009814.

Fu, X., Feng, X., Zhang, H., Yu, B., Chen, L. (2012) Mercury emissions from natural surfaces highly impacted by human activities in Guangzhou province, South China. Atmospheric Environmental 54, 185-193.

Gabriel, M.C., Williamson, D.G., Zhang, H., Brooks, S., Lindberg, S. (2006) Diurnal and seasonal trends in total gaseous mercury flux from three urban ground surfaces. Atmospheric Environmental 40, 4269-4284.

Gustin, M.S., Stamenkovic, J. (2005) Effect of watering and soil moisture on mercury emissions from soils. Biogeochemistry 76, 215-232.

Hamlett, N.V., Landale, E.C., Davis, B.H., Summers, A.O. (1992) Roles of the Tn21 merT, merP, and merC gene products in mercury resistance and mercury binding. Journal of Bacteriology 174, 6377-6385.

Kim, K.H., Kim, K.Y. (1999) The exchange of gaseous mercury across soil-air interface in a residential area of Soul, Korea. Atmospheric Environmental 33, 31533165.

King, J.K., Harmon, S.M., Fu, T.T., Gladden, J.B. (2002) Mercury removal, methylmercury formation, and sulfate-reducing bacteria profiles in wetland mesocosms. Chemosphere 46, 859-870.

Kocman, D., Horvat, M. (2010) A laboratory based experimental study of mercury emission from contaminated soils in the River Idrijca catchment. Atmospheric Chemistry and Physics 10, 1417-1426.

Leonard, T.L., Taylor, G.E., Gustin, M.S., Fernandez, G.C.J. (1998) Mercury and plants in contaminated soils: 1. Uptake, partitioning, and emission to the atmosphere. Environmental Toxicology and Chemistry 17, 20632071.

Lin, C.J, Gustin, M.S., Singhasuk, P., Eckley, C., Miller, M. (2010) Empirical models for estimating mercury flux from soils. Environmental Science \& Technology $44,8522-8528$.

Lindberg, S.E., Zhang, H., Vette, A.F., Gustin, M.S., Barnett, M.O., Kuiken, T. (2002) Dynamic flux chamber measurement of gaseous mercury emission fluxes over soils: Part 2 - Effect of flushing flow rate and verification of a two-resistance exchange interface simulation model. Atmospheric Environmental 36, 847-859.

Mauclair, C., Layshock, J., Carpi, A. (2008) Quantifying the effect of humic matter on the emission of mercury from artificial soil surfaces. Applied Geochemistry 23, 594-601.

Meili, M. (1991) The coupling of mercury and organic matter in the biogeochemical cycle-towards a mechanistic model for the boreal forest zone. Water Air Soil Pollution 56, 333-347.

Nelson, D.W., Sommers, L.E. (1996) Total carbon, organic carbon, and organic matter. In (Sparks, D.L., Page, A.L., Helmke, P.A., Loeppert, R.H., Soltanpour, P.N., 
Tabatabai, M.A., Johnston, C.T. and Sumner, M.E. Eds.), Methods of Soil Analysis. Part 3: Chemical Methods. American Society of Agronomy, Inc. and Soil Science Society of America, Inc., Madison, Wisconsin, 961-1010.

Poissant, L., Casimir, A. (1998) Water-air and soil-air exchange rate of total gaseous mercury measured at background sites. Atmospheric Environmental 32, 883-893.

Poissant, L., Amyot, M., Pilote, M., Lean, D. (2000) Mercury water-air exchange over the upper St. Lawrence river and Lake Ontario. Environmental Science \& Technology 34, 3069-3078.

Savitzky, A., Golay, M.J.E. (1964) Smoothing and differentiation of data by simplified least squares procedure. Analytical Chemistry 36, 19627-1639.

Schlüter, K. (2000) Review; evaporation of mercury from soils. An integration and synthesis of current knowledge. Environmental Geology 39, 249-271.

Scholtz, M.T., Van Heyst, B.J., Schroeder, W.H. (2003) Modelling of mercury emissions from background soils. Science Total Environmental 304, 185-207.

Schroeder, W.H., Beauchamp, S., Edwards, G., Poissant, L., Rasmussen, P. (2005) Gaseous mercury emissions from natural sources in Canadian landscapes. Journal of Geophysical Research 110 (D18302). doi:10.1029/ 2004JD005699.

Schuster, E. (1991) The behavior of mercury in the soil with special emphasis on complexation and adsorption processes - a review of the literature. Water Air Soil Pollution 56, 667-680.

Skinner, D. (1998) UV curing through semi-transparent materials: the challenge of the DVD bonding process. In: The RadTech International North America 98 Conference, Chicago, IL.

Skyllberg, U., Bloom, P.R., Qian, J., Lin, C.-M., Bleam, W.F. (2006) Complexation of mercury (II) in soil organic matter: EXAFS evidence for linear two-coordination with reduced sulfur groups. Environmental Science Technology 40, 4174-4180.

Smith, T., Pitts, K., McGarvey, J.A., Summers, A.O. (1998) Bacterial oxidation of mercury metal vapor, $\mathrm{Hg}(0)$.
Applied and Environmental Microbiology 64, 13281332.

Stamerkovic, J., Gustin, M.S., Arnone, J.A., Johnson, D.W., Larsen, J.D., Verburg, P.S.J (2008) Atmospheric mercury exchange with a tallgrass prairie ecosystem housed in mesocosms. Science of Total Environmental 406, 227-238.

Summers, A.O., Silver, S. (1972) Mercury resistance in a plasmid-bearing strain of Excherichia coli. Journal of Bacteriology 112, 1228-1236.

UNEP (2013) Global mercury assessment 2013; Source, emissions, releases and environmental transport.

Wallschlager, D., Kock, H.H., Schroeder, W.H., Lindberg, S.E., Ebinghaus, R., Wilken, R.D. (2000) Mechanism and significance of mercury volatilization from contaminated floodplains of the German river Elbe. Atmospheric Environmental 34, 3745-3755.

Xin, M., Gustin, M., Johnson, D. (2007) Laboratory investigation of the potential for re-emission of atmospherically derived $\mathrm{Hg}$ from soils. Environmental Science Technology 41, 4946-4951.

Yang, Y.K., Cheng, Z., Shi, X.J., Lin, T., Wang, D.Y. (2007) Effect of organic matter and pH on mercury release from soils. Journal of Environmental Science 19, 1349-1354.

Zhang, H., Lindberg, S.E. (2001) Sunlight and iron(III)induced photochemical production of dissolved gaseous mercury in freshwater. Environmental Science Technology 35(5), 928-935.

Zhang, H., Lindberg, S.E. (1999) Processes influencing the emission of mercury from soils: A conceptual model. Journal of applied Geophysical Research 104(D17), 21889-21896.

Zhang, H., Lindberg, S.E., Kuiken, T. (2008) Mysterious diel cycles of mercury emission from soils held in the dark at constant temperature. Atmospheric Environmental 42, 5424-5433.

(Received 12 August 2013, revised 23 October 2013, accepted 22 November 2013) 